\title{
Evaluation of NO Oxidation Properties over a $\mathrm{Mn}-\mathrm{Ce} / \gamma-\mathrm{Al}_{2} \mathrm{O}_{3}$ Catalyst
}

\author{
Pan Wang, Peng Luo, Junchen Yin, and Lili Lei \\ School of Automotive and Traffic Engineering, Jiangsu University, Zhenjiang 212013, China \\ Correspondence should be addressed to Pan Wang; wangpan@ujs.edu.cn
}

Received 3 March 2016; Accepted 12 April 2016

Academic Editor: Renyun Zhang

Copyright (C) 2016 Pan Wang et al. This is an open access article distributed under the Creative Commons Attribution License, which permits unrestricted use, distribution, and reproduction in any medium, provided the original work is properly cited.

With the purpose of studying the effect of diesel oxidation catalyst (DOC) on the NO oxidation activity, a series of $x \mathrm{Mn} 10 \mathrm{Ce} / \gamma$ $\mathrm{Al}_{2} \mathrm{O}_{3}(x=4,6,8$, and 10) catalysts were synthesized by acid-aided sol-gel method. The physicochemical properties of the catalysts were characterized by X-ray diffraction (XRD), scanning electron microscope (SEM), and Transmission Electron Microscope (TEM). Result showed that the crystalline size of $\mathrm{MnO}_{x}$ and $\mathrm{CeO}_{2}$ ranges from $5 \mathrm{~nm}$ to $30 \mathrm{~nm}$ and manganese existed mainly in the catalysts in the form of manganese dioxide. Moreover, $\mathrm{NO}$ oxidation experiments were carried out to evaluate the activity of the catalysts; according to the results, $6 \mathrm{Mn} 10 \mathrm{Ce} / \gamma-\mathrm{Al}_{2} \mathrm{O}_{3}$ catalyst showed the supreme $\mathrm{NO}$ oxidation activity with a $\mathrm{NO}$ to $\mathrm{NO}_{2}$ conversion rate of $83.5 \%$ at $300^{\circ} \mathrm{C}$. Compared to $500 \mathrm{ppm} \mathrm{NO}$ inlet concentration, the NO conversion was higher than that of 750 and $1000 \mathrm{ppm} \mathrm{NO}$ over $6 \mathrm{Mn} 10 \mathrm{Ce} / \gamma-\mathrm{Al}_{2} \mathrm{O}_{3}$ catalyst in the temperature range of $150-300^{\circ} \mathrm{C}$.

\section{Introduction}

Diesel engines are widely used as commercial vehicle power due to the higher thermal efficiency, durability, and fuel economy compared to gasoline engines. However, with increasingly stringent vehicle exhaust gas emission regulations and the attention to health, the $\mathrm{NO}_{x}\left(\mathrm{NO}, \mathrm{NO}_{2}\right)$ emission from diesel engines that caused many serious environmental problems, such as acid rain and photochemical smog, has met severe challenge $[1,2]$.

Recently, catalysis technique adopted to oxidize NO to $\mathrm{NO}_{2}$ has been attracting enormous attention due to its role in several catalytic processes, such as $\mathrm{NO}_{x}$ reduced by SCR with hydrocarbons and soot combustion in the atmosphere of $\mathrm{NO}_{x} / \mathrm{O}_{2}[3,4]$. The diesel oxidation catalyst (DOC) can not only oxidize $\mathrm{CO}, \mathrm{HC}$, and $\mathrm{PM}$, but also facilitate the oxidation of $\mathrm{NO}$ to $\mathrm{NO}_{2}$, which is beneficial for $\mathrm{NO}_{x}$ removal by the downstream SCR or NSR units $[5,6]$; for urea SCR, a $\mathrm{NO}_{2}$ : NO ratio of $1: 1$ is the most effective. In the NSR process, $\mathrm{NO}$ needs to be oxidized to $\mathrm{NO}_{2}$ before being absorbed by storage components during the lean phase. However, according to the literature [7], the amount of $\mathrm{NO}_{2}$ in diesel engine exhaust is usually less than $10 \%$ in the total $\mathrm{NO}_{x}$. Hence, to improve the $\mathrm{NO}_{2} / \mathrm{NO}_{x}$ ration is of great necessity for the sake of improving the posttreatment efficiency.

Many metal mixed catalysts, such as $\mathrm{CeO}_{2} / \mathrm{ZrO}_{2}$ [8] and $\mathrm{MnO}_{x}-\mathrm{TiO}_{2}$ [9], can effectively oxidize $\mathrm{NO}$ to $\mathrm{NO}_{2}$. The $\mathrm{MnO}_{x}-\mathrm{CeO}_{2}$ mixed oxides have been reported to have much higher catalytic activities compared to the individual $\mathrm{CeO}_{2}$ and $\mathrm{MnO}_{x}$, for the reason that the strong interaction between $\mathrm{MnO}_{x}$ and $\mathrm{CeO}_{2}$ can form solid solution [10, 11]. $\mathrm{Li}$ and coworkers reported that $\mathrm{Mn}$-Ce oxides were active for $\mathrm{NO}$ to $\mathrm{NO}_{2}$ oxidation with about $80 \% \mathrm{NO}$ conversion at $150^{\circ} \mathrm{C}$ over $\mathrm{Mn}-\mathrm{Co}-\mathrm{Ce}(20)-400$ catalyst [12]. According to the literatures [13-16], $\mathrm{CeO}_{2}$ has been widely studied for its oxygen storage and redox properties, among which the most important property is that ceria can store and release oxygen via the redox shift between $\mathrm{Ce}^{4+}$ and $\mathrm{Ce}^{3+}$ under oxidizing and reducing conditions.

In this work, in order to study the $\mathrm{NO}$ oxidation performance by DOC, $\mathrm{Mn}-\mathrm{Ce} / \gamma-\mathrm{Al}_{2} \mathrm{O}_{3}$ mixed oxides catalyst was synthesized by acid-aided sol-gel method. X-ray diffraction (XRD), scanning electron microscope (SEM), and Transmission Electron Microscope (TEM) were carried out to 
investigate the physicochemical properties of the catalyst structure, and $\mathrm{NO}$ oxidation experiments were carried out to evaluate the activities of the catalysts.

\section{Experimental}

2.1. Catalyst Preparation. A series of $x \mathrm{Mn} 10 \mathrm{Ce} / \gamma-\mathrm{Al}_{2} \mathrm{O}_{3}(x=$ $4,6,8$, and 10 , wt\%) catalysts were prepared by acidaided sol-gel method as described in the literature [17]. First, $\mathrm{Ce}\left(\mathrm{NO}_{3}\right)_{3} \cdot 6 \mathrm{H}_{2} \mathrm{O}, \mathrm{C}_{4} \mathrm{H}_{6} \mathrm{MnO}_{4} \cdot 4 \mathrm{H}_{2} \mathrm{O}$, and $\gamma-\mathrm{Al}_{2} \mathrm{O}_{3}$ were weighed by different $\mathrm{Mn} / \mathrm{Ce}$ molar ratio and dissolved in deionized water, respectively, to obtain solution, into which citric acid was added, the amount of which was twice the sum of $\mathrm{Ce}^{3+}$ and $\mathrm{Mn}^{2+}$ total molar. Then polyethylene glycol, the quality of which is $10 \%$ of the citric acid, was introduced and magnet-stirred at $80^{\circ} \mathrm{C}$ until transparent gel was obtained. Then it was dried at $110^{\circ} \mathrm{C}$ for $24 \mathrm{~h}$ and calcined in air for $5 \mathrm{~h}$ at $500^{\circ} \mathrm{C}$. Then the powder was ball-milled to obtain the required 20-40-mesh powder.

2.2. Catalyst Characterization. X-ray diffraction (XRD) of the as-prepared sample was measured on a Bruker D8 ADVANCE X-ray diffractometer with a Ni-filtered $\mathrm{Cu} \mathrm{K \alpha}$ $(\lambda=0.154068 \mathrm{~nm})$ radiation source at $40 \mathrm{kV}$ and $40 \mathrm{~mA}$. Powder XRD patterns were recorded at $0.02^{\circ}$ interval in the range of $20^{\circ} \leq 2 \theta \leq 80^{\circ}$ with a scanning velocity of $7^{\circ} \mathrm{min}^{-1}$. The crystalline size was calculated by Scherrer's formula $D=\mathrm{K} \lambda /(\beta \cos \theta)$. Transmission Electron Microscope (TEM) measurement was done by using a Philips Tecnai 12 microscope, with a $120 \mathrm{kV}$ accelerating voltage. Before testing, the catalyst powder was ground and dispersed ultrasonically in anhydrous ethanol and then dropped onto a carbon-coated $\mathrm{Cu}$ grid of 200 mesh. Scanning electron microscope (SEM) testing was performed on JSM-7001F microscope made by JEOL. Accelerating voltage was $0.5-30 \mathrm{kV}$, magnification $10-$ $800 \mathrm{~K}$, and resolution $1.2 \mathrm{~nm}(30 \mathrm{kV}) / 3.0 \mathrm{~nm}(1 \mathrm{kV})$.

2.3. Catalyst Evaluation. The oxidation of $\mathrm{NO}$ to $\mathrm{NO}_{2}$ activity was measured at the temperatures in the range of 150 $450^{\circ} \mathrm{C}$. The catalysts were placed in a fixed-bed quartz mircoreactor with an inside diameter of $10 \mathrm{~mm}$ and plugged and sandwiched between two silica wool layers to prevent the sample from being blown away. The gases used in the tests were $500 \mathrm{ppm} \mathrm{NO}, 10 \% \mathrm{O}_{2}$, and $\mathrm{N}_{2}$ in balance with a total flow rate of $280 \mathrm{~mL} / \mathrm{min}$, giving a space velocity of $56,000 \mathrm{~h}^{-1}$. The outlet $\mathrm{NO}$ and $\mathrm{NO}_{2}$ concentrations were detected by Thermo Scientific Model 42i-HL $\mathrm{NO}_{x}$ Analyzer. Before each NO oxidation experiment, the catalyst sample was heated to $450^{\circ} \mathrm{C}$ in $\mathrm{N}_{2}$ atmosphere for $30 \mathrm{~min}$, in order to clean up the residual gases adsorbed in the catalyst surface, and then cooled to the required measurement temperatures.

\section{Results and Discussion}

3.1. XRD Characterization. The X-ray diffraction patterns of $x \mathrm{Mn} 10 \mathrm{Ce} / \gamma-\mathrm{Al}_{2} \mathrm{O}_{3}(x=4,6,8$, and 10$)$ catalysts are shown in Figure 1. As can be seen in Figure 1, all the samples exhibit characteristic peaks of $\gamma-\mathrm{Al}_{2} \mathrm{O}_{3}$ at $2 \theta=25.74^{\circ}, 35.32^{\circ}, 37.93^{\circ}$,

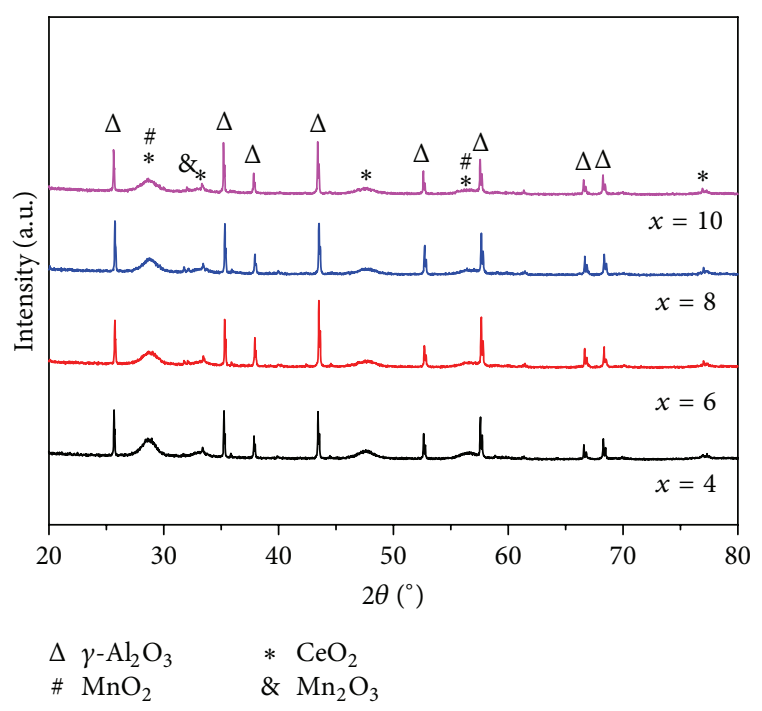

FIGURE 1: XRD pattern of $x \mathrm{Mn} 10 \mathrm{Ce} / \gamma-\mathrm{Al}_{2} \mathrm{O}_{3}$ catalysts.

$43.53^{\circ}, 53.72^{\circ}, 57.65^{\circ}, 66.68^{\circ}$, and $68.36^{\circ}$ (JCPDS: PDF 100173). The main diffraction peaks at $2 \theta=28.880^{\circ}, 33.652^{\circ}$, $47.918^{\circ}$, and $56.762^{\circ}$ were attributed to the (111), (200), (220), and (311) planes of cubic fluorite $\mathrm{CeO}_{2}$ (JCPDS: PDF43-1002) $[18,19]$. Moreover, the diffraction peaks of $\mathrm{CeO}_{2}$ shifted to lower degrees for about $0.5^{\circ}$, the reason of which is that a part of $\mathrm{Ce}^{4+}$ ions is replaced by $\mathrm{Mn}^{4+}$ and $\mathrm{Mn}^{3+}$ to form solid solution [20]. According to Scherrer's formula, the crystalline size of $\mathrm{CeO}_{2}$ (111) is $26 \mathrm{~nm}$. Other two diffraction peaks at $2 \theta=28.823^{\circ}$ and $56.197^{\circ}$ (which are overlapped with the peaks of $\mathrm{CeO}_{2}$ ) are identified as the phase of $\mathrm{MnO}_{2}$ (JCPDS: PDF 65-7467). In addition, when $x=4$, the diffraction peaks of $\mathrm{Mn}_{2} \mathrm{O}_{3}$ are not detected by XRD, which is in accordance with the small amount of manganese oxides, while the intensity increased with $x$ (when $x \geq 6$ ).

3.2. SEM and EDS Analysis. SEM analysis of as-prepared catalysts was used to elucidate the surface morphology and distribution of the different components present. Figure 2(a) shows the micrograph of $6 \mathrm{Mn} 10 \mathrm{Ce} / \gamma-\mathrm{Al}_{2} \mathrm{O}_{3}$ catalyst. As can be seen, the catalyst presents a morphology in the form of crisscrossed nanorods, which is $\gamma-\mathrm{Al}_{2} \mathrm{O}_{3}$, on which there are some particles of $10-30 \mathrm{~nm}$ (red circles) deposited that are $\mathrm{CeO}_{2}$ nanoparticles; the result is in accordance with the XRD (the size of $\mathrm{CeO}_{2}$ particle is $26 \mathrm{~nm}$ ). In addition, some agglomerate particles with different sizes (80-300 nm) also deposited on $\gamma-\mathrm{Al}_{2} \mathrm{O}_{3}$, which can be the aggregates of $\mathrm{MnO}_{x}$ and $\mathrm{CeO}_{2}$ (black circles). Figure 2(b) shows the surface elements of the sample; the main elements are $\mathrm{Al}, \mathrm{Mn}, \mathrm{Ce}$, $\mathrm{O}$, and $\mathrm{C}$, which are from the white box area in Figure 2(a), among which the presence of $\mathrm{C}$ element can be attributed to the decomposition of citric acid and $\mathrm{C}_{4} \mathrm{H}_{6} \mathrm{MnO}_{4} \cdot 4 \mathrm{H}_{2} \mathrm{O}$ at high temperature during calcination.

3.3. TEM Analysis. TEM is executed to ascertain the morphology of the catalyst. Figure 3 shows the morphology of $6 \mathrm{Mnl} 10 \mathrm{Ce} / \gamma-\mathrm{Al}_{2} \mathrm{O}_{3}$ catalyst. Obviously, the main structure of 


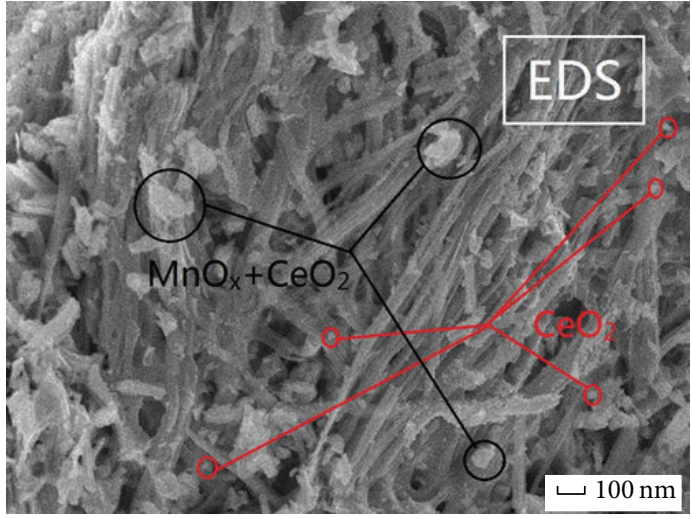

(a)

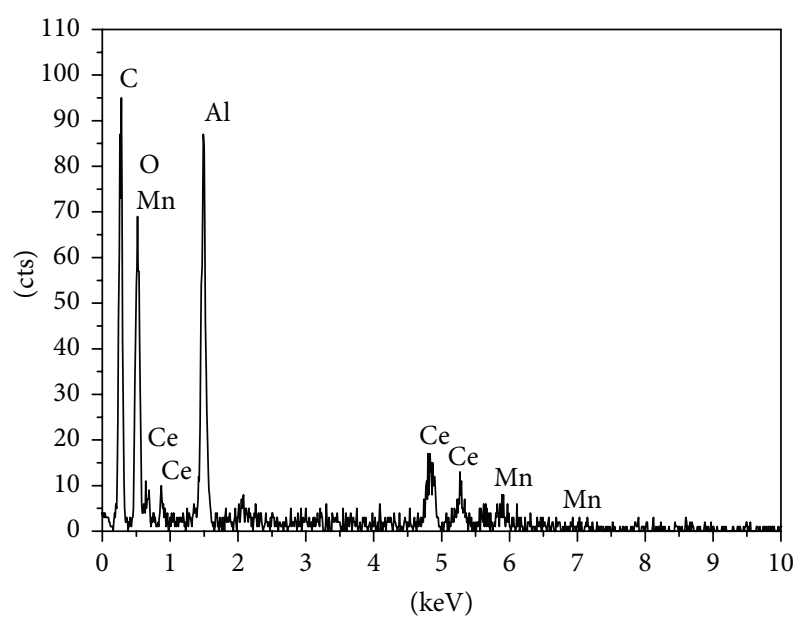

(b)

FIgURE 2: (a) SEM micrograph of $6 \mathrm{Mn} 10 \mathrm{Ce} / \gamma-\mathrm{Al}_{2} \mathrm{O}_{3}$ catalyst. (b) EDS pattern.

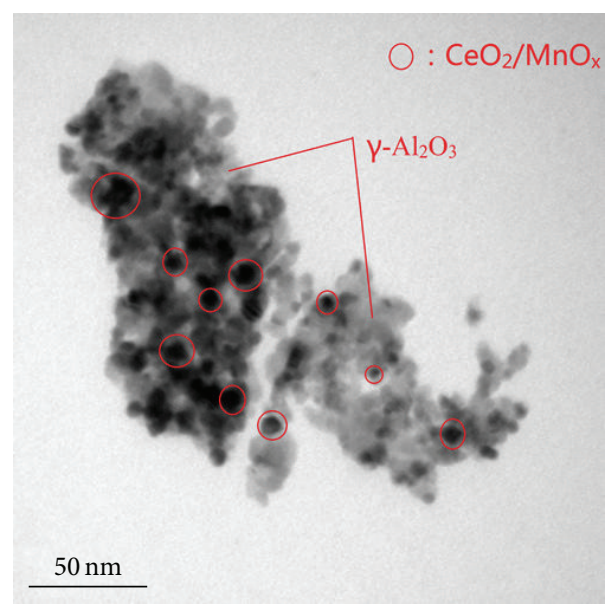

FIGURE 3: TEM pattern of $6 \mathrm{Mn} 10 \mathrm{Ce} / \gamma-\mathrm{Al}_{2} \mathrm{O}_{3}$ catalyst.

the catalyst is strip-shaped with nanosize, which is similar to the SEM analysis results. The small near-spherical particles with the size of about 5 30 $\mathrm{nm}$ (marked by the red circles), homogeneously dispersed on the surface of the catalyst, could be regarded as $\mathrm{CeO}_{2}$ or $\mathrm{MnO}_{x}$ nanoparticles. Besides, the darker zone on the TEM pattern indicates a certain degree of aggregation between $\mathrm{CeO}_{2}$ and $\mathrm{MnO}_{x}$.

3.4. Effect of Temperature on NO Conversion. Results on NO conversion as a function of temperature over $x \mathrm{Mn} 10 \mathrm{Ce} / \gamma$ $\mathrm{Al}_{2} \mathrm{O}_{3}(x=4,6,8$, and 10) catalysts are given in Figure 4 . It is obvious that, in the range of $150^{\circ} \mathrm{C}$ to $300^{\circ} \mathrm{C}$, NO conversion of all the catalysts increased with temperature, but when temperature is above $300^{\circ} \mathrm{C}$, NO conversion decreased with temperature except for $4 \mathrm{Mn} 10 \mathrm{Ce} / \gamma-\mathrm{Al}_{2} \mathrm{O}_{3}$ catalyst (maximum $\mathrm{NO}$ conversion at $350^{\circ} \mathrm{C}$ ). The $\mathrm{NO}$ conversion rate decreased mainly due to the accelerated thermal decomposition of $\mathrm{NO}_{2}$ under the influence of high temperature. In the whole range of temperature, the steady-state NO conversion goes

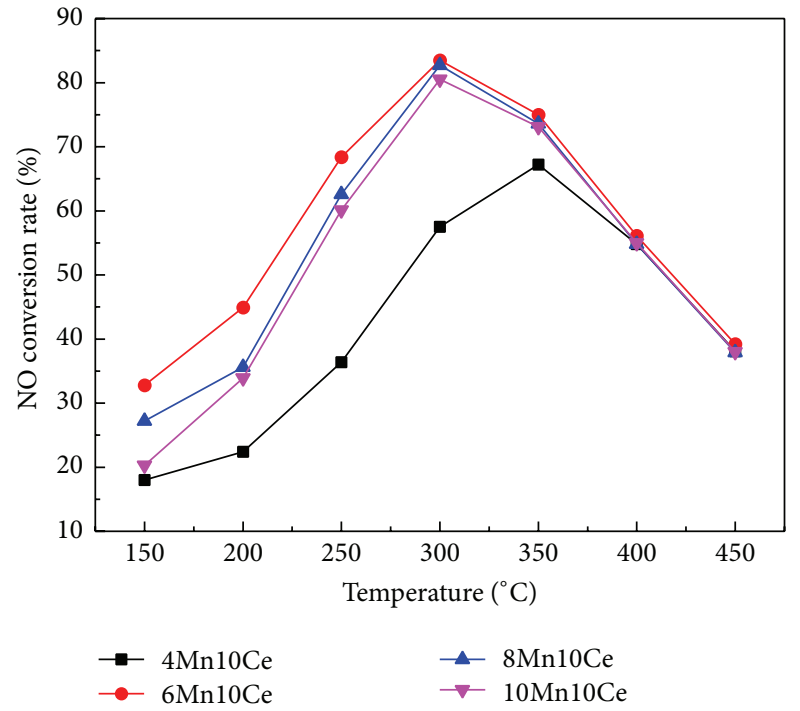

Figure 4: Oxidation activity of $\mathrm{NO}$ to $\mathrm{NO}_{2}$ by $\mathrm{O}_{2}$ on $x \mathrm{Mn} 10 \mathrm{Ce} / \gamma$ $\mathrm{Al}_{2} \mathrm{O}_{3}(x=4,6,8$, and 10) catalysts at different temperatures (the conditions: $500 \mathrm{ppm} \mathrm{NO}, 10 \% \mathrm{O}_{2}, \mathrm{~N}_{2}$ in balance and $280 \mathrm{~mL} / \mathrm{min}$ total flow rate, and space velocity $56,000 \mathrm{~h}^{-1}$ ).

through a maximum of $83.5 \%$ at temperature of $300^{\circ} \mathrm{C}$ on $6 \mathrm{Mn} 10 \mathrm{Ce} / \gamma-\mathrm{Al}_{2} \mathrm{O}_{3}$ catalyst, followed by $8 \mathrm{Mn} 10 \mathrm{Ce} / \gamma-\mathrm{Al}_{2} \mathrm{O}_{3}$ $\left(82.7 \%\right.$ at $\left.300^{\circ} \mathrm{C}\right), 10 \mathrm{Mn} 10 \mathrm{Ce} / \gamma-\mathrm{Al}_{2} \mathrm{O}_{3}\left(80.5 \%\right.$ at $\left.300^{\circ} \mathrm{C}\right)$, and $4 \mathrm{Mn} 10 \mathrm{Ce} / \gamma-\mathrm{Al}_{2} \mathrm{O}_{3}\left(67.2 \%\right.$ at $\left.350^{\circ} \mathrm{C}\right)$. Compared with other catalysts, $6 \mathrm{Mn} 10 \mathrm{Ce} / \gamma-\mathrm{Al}_{2} \mathrm{O}_{3}$ presented better $\mathrm{NO}$ oxidation activity. The reason was that the properties of the catalysts depend mainly on the active components, especially the $\mathrm{Mn} / \mathrm{Ce}$ ratio. According to the research by Qi and Li [21], $\mathrm{MnO}_{x}$ are the main contributor for $\mathrm{NO}$ oxidation. Hence, with the increase of $\mathrm{MnO}_{x}$, the catalysts showed better oxidation capacity, while the average chemical valence of $\mathrm{Mn}^{4+}$ decreased; the interaction between catalysts activities and Mn content is nonlinear. Therefore, in our research, the 


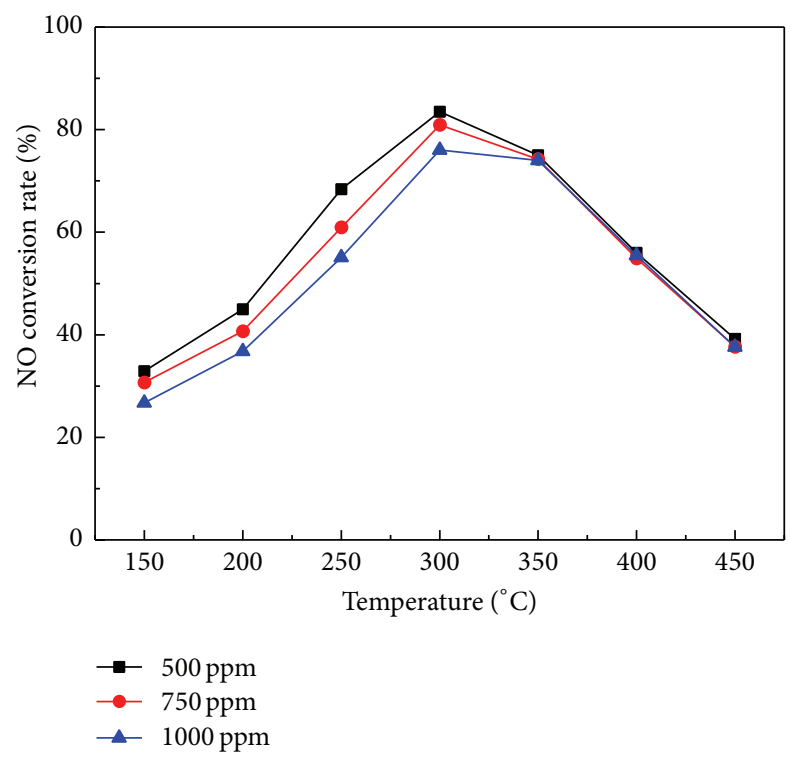

FIgURE 5: Oxidation activity of $\mathrm{NO}$ to $\mathrm{NO}_{2}$ by $\mathrm{O}_{2}$ on $6 \mathrm{Mn} 10 \mathrm{Ce} / \gamma$ $\mathrm{Al}_{2} \mathrm{O}_{3}$ catalyst at different temperatures (the conditions: 500, 750, and $1000 \mathrm{ppm} \mathrm{NO}, 10 \% \mathrm{O}_{2}, \mathrm{~N}_{2}$ in balance and $280 \mathrm{~mL} / \mathrm{min}$ total flow rate, and space velocity $56,000 \mathrm{~h}^{-1}$ ).

catalyst obtained the best NO oxidation activity when the $\mathrm{Mn} / \mathrm{Ce}$ ratio is $6 / 10$.

3.5. Effect of NO Concentration on NO Conversion. As described above, the $6 \mathrm{Mn} 10 \mathrm{Ce} / \gamma-\mathrm{Al}_{2} \mathrm{O}_{3}$ catalyst showed the best activity on $\mathrm{NO}$ to $\mathrm{NO}_{2}$ conversion of $83.5 \%$ at $300^{\circ} \mathrm{C}$. In order to further study the effect of inlet $\mathrm{NO}$ concentrations on the $\mathrm{NO}$ to $\mathrm{NO}_{2}$ oxidation activity, the experiment, in the atmosphere of 500, 750, and 1000 ppm NO in $10 \% \mathrm{O}_{2}$ with $\mathrm{N}_{2}$ as balance, respectively, was carried out. The NO conversion rate was calculated when the outlet $\mathrm{NO}$ concentration stabilized for $400 \mathrm{~s}$. Results on $\mathrm{NO}$ conversion as a function of temperature over $6 \mathrm{Mn} 10 \mathrm{Ce} / \gamma-\mathrm{Al}_{2} \mathrm{O}_{3}$ catalyst are given in Figure 5. The result indicates that, in the range of $150-300^{\circ} \mathrm{C}$, when inlet NO was 500 ppm, NO conversion rate was $32.9 \%-$ $83.5 \%$. In addition, with inlet NO concentration increasing, the $\mathrm{NO}$ conversion deceased by around $3 \%(\mathrm{NO}=750 \mathrm{ppm})$ and $5 \%(\mathrm{NO}=1000 \mathrm{ppm})$, respectively. Moreover, the NO conversion was almost maintained the same, whatever the inlet $\mathrm{NO}$ concentration in the range of $350-450^{\circ} \mathrm{C}$ was. However, the catalysts are sensitive to other pollution gases, such as $\mathrm{SO}_{2}, \mathrm{CO}$, and $\mathrm{H}_{2} \mathrm{O}$, which was still needed for further research.

\section{Conclusions}

In the present work, a series of $x \mathrm{Mn} 10 \mathrm{Ce} / \gamma-\mathrm{Al}_{2} \mathrm{O}_{3}(x=4,6,8$, and 10) catalysts were prepared by acid-aided sol-gel method and found to be well crystallized and dispersed, $\mathrm{CeO}_{2}$ and $\mathrm{MnO}_{x}$ with the crystalline size of 5-30 nm. Compared with other catalysts, $6 \mathrm{Mn} 10 \mathrm{Ce} / \gamma-\mathrm{Al}_{2} \mathrm{O}_{3}$ catalyst showed higher activity for $\mathrm{NO}$ oxidation to $\mathrm{NO}_{2}$ over the temperature range of $150-450^{\circ} \mathrm{C}$, up to $83.5 \%$ at $300^{\circ} \mathrm{C}$.
In addition, $\mathrm{NO}$ oxidation to $\mathrm{NO}_{2}$ was further studied under different $\mathrm{NO}$ concentrations over $6 \mathrm{Mn10Ce} / \gamma-\mathrm{Al}_{2} \mathrm{O}_{3}$ catalyst. Generally, NO conversion augmented rapidly with temperature elevating in the range of $150-300^{\circ} \mathrm{C}$ for all different $\mathrm{NO}$ conditions. On the contrary, $\mathrm{NO}$ conversion decreased with temperature above $300^{\circ} \mathrm{C}$. NO conversion reached maximum of $83.5 \%, 80.9 \%$, and $76 \%$ for $500 \mathrm{ppm}$, $750 \mathrm{ppm}$, and $1000 \mathrm{ppm}$ NO concentration, respectively, at $300^{\circ} \mathrm{C}$. We also found that there was almost no effect of $\mathrm{NO}$ concentration on $\mathrm{NO}$ conversion above $350^{\circ} \mathrm{C}$.

\section{Competing Interests}

The authors declare that there are no competing interests regarding the publication of this paper.

\section{Acknowledgments}

Financial support of this paper was provided by the National Natural Science Foundation (51206068), Natural Science Foundation of Jiangsu Province (BK2015040369), and State Key Laboratory of Engines, Tianjin University (K15-007).

\section{References}

[1] F. Cao, J. Xiang, S. Su, P. Wang, S. Hu, and L. Sun, "Ag modified $\mathrm{Mn}-\mathrm{Ce} / \gamma-\mathrm{Al}_{2} \mathrm{O}_{3}$ catalyst for selective catalytic reduction of $\mathrm{NO}$ with $\mathrm{NH}_{3}$ at low-temperature," Fuel Processing Technology, vol. 135, pp. 66-72, 2015.

[2] V. Sanchez-Escribano, T. Montanari, and G. Busca, "Low temperature selective catalytic reduction of NOx by ammonia over H-ZSM-5: An IR study," Applied Catalysis B: Environmental, vol. 58, no. 1-2, pp. 19-23, 2005.

[3] C. Thomas, O. Gorce, F. Villain, and G. Djéga-Mariadassou, "Influence of the nature of the noble metal on the lean $\mathrm{C}_{3} \mathrm{H}_{6}$ assisted decomposition of $\mathrm{NO}$ on $\mathrm{Ce}_{0.68} \mathrm{Zr}_{0.32} \mathrm{O}_{2}$-supported catalysts," Journal of Molecular Catalysis A: Chemical, vol. 249, no. 1-2, pp. 71-79, 2006.

[4] A. Russell and W. S. Epling, "Diesel oxidation catalysts," Catalysis Reviews: Science and Engineering, vol. 53, no. 4, pp. 337-423, 2011.

[5] I. Atribak, I. Such-Basanez, A. Bueno-Lopez et al., "Comparison of the catalytic activity of $\mathrm{MO}_{2}(\mathrm{M}=\mathrm{Ti}, \mathrm{Zr}, \mathrm{Ce})$ for soot oxidation under $\mathrm{NO}_{x} / \mathrm{O}_{2}$," Achiv Fur Physikalische Therapie, vol. 250, no. 1, pp. 75-84, 2007.

[6] J. Štěpánek, P. Kočí, F. Plát, M. Marek, and M. Kubíček, "Investigation of combined DOC and NSRC diesel car exhaust catalysts," Computers and Chemical Engineering, vol. 34, no. 5, pp. 744-752, 2010.

[7] G. Qi and W. Li, "NO oxidation to $\mathrm{NO}_{2}$ over manganese-cerium mixed oxides," Catalysis Today, vol. 258, no. 1, pp. 205-213, 2015.

[8] Z. B. Wu, N. Tang, L. Xiao, Y. Liu, and H. Wang, " $\mathrm{MnO}_{\mathrm{x}} / \mathrm{TiO}_{2}$ composite nanoxides synthesized by deposition-precipitation method as a superior catalyst for NO oxidation," Journal of Colloid and Interface Science, vol. 352, no. 1, pp. 143-148, 2010.

[9] I. Atribak, N. Guillén-Hurtado, A. Bueno-López, and A. GarcíaGarcía, "Influence of the physico-chemical properties of $\mathrm{CeO}_{2}$ $\mathrm{ZrO}_{2}$ mixed oxides on the catalytic oxidation of $\mathrm{NO}$ to $\mathrm{NO}_{2}$," Applied Surface Science, vol. 256, no. 24, pp. 7706-7712, 2010. 
[10] X. F. Tang, Y. G. Li, X. M. Huang et al., " $\mathrm{MnO}_{x}-\mathrm{CeO}_{2}$ mixed oxide catalysts for complete oxidation of formaldehyde: effect of preparation method and calcination temperature," Applied Catalysis B: Environmental, vol. 62, no. 3-4, pp. 265-273, 2006.

[11] H. Chen, A. Sayari, A. Adnot, and F. Larachi, "Compositionactivity effects of $\mathrm{Mn}$-Ce-O composites on phenol catalytic wet oxidation," Applied Catalysis B: Environmental, vol. 32, no. 3, pp. 195-204, 2001.

[12] K. Li, X. L. Tang, H. H. Yi, P. Ning, D. Kang, and C. Wang, "Low-temperature catalytic oxidation of $\mathrm{NO}$ over $\mathrm{Mn}-\mathrm{Co}-\mathrm{Ce}-$ Ox catalyst," Chemical Engineering Journal, vol. 192, pp. 99-104, 2012.

[13] S. F. Shi, Y. Q. Wang, J. C. Ma et al., "The preparation and performance of $\mathrm{Ni}-\mathrm{La} / \mathrm{Ce}_{x} \mathrm{Zr}_{1-x} \mathrm{O}_{2}$ catalysts for coupled methane partial oxidation/ $\mathrm{CH}_{4}-\mathrm{CO}_{2}$ reforming to syngas," Journal of Molecular Catalysis (China), vol. 27, no. 6, pp. 539-547, 2013.

[14] S.-J. Wang, G.-C. Zou, Y. Xu et al., "Ce-based catalysts for simultaneous removal of both diesel soot and $\mathrm{NO}_{x}$," Journal of Molecular Catalysis, vol. 29, no. 1, pp. 60-67, 2015.

[15] L. W. Jia, M. Q. Shen, J. Wang, J. Wang, X. Chu, and W. Gu, "Durability of three-way and close-coupled catalysts for Euro IV regulation," Journal of Rare Earths, vol. 26, no. 6, pp. 827830, 2008.

[16] H. Li, X. Tang, H. Yi, and L. Yu, "Low-temperature catalytic oxidation of NO over Mn-Ce-O $\mathrm{O}_{x}$ catalyst," Journal of Rare Earths, vol. 28, no. 1, pp. 64-68, 2010.

[17] D. Delimaris and T. Ioannides, "VOC oxidation over $\mathrm{MnO}_{x}{ }^{-}$ $\mathrm{CeO}_{2}$ catalysts prepared by a combustion method," Applied Catalysis B: Environmental, vol. 84, no. 1-2, pp. 303-312, 2008.

[18] C. Ming, D. Q. Ye, H. Liang, and H. Liu, "Catalytic combustion performance of soot over cerium-based transition metal composite oxide catalysts," Acta Scientiae Circumstantiae, vol. 30, no. 1, pp. 158-164, 2010.

[19] R. O. Fuentes and R. T. Baker, "Synthesis of nanocrystalline $\mathrm{CeO}_{2}-\mathrm{ZrO}_{2}$ solid solutions by a citrate complexation route: a thermochemical and structural study," The Journal of Physical Chemistry C, vol. 113, no. 3, pp. 914-924, 2009.

[20] Y. Rui, Y. Zhang, D. Liu et al., "A series of ceria supported lean-burn $\mathrm{NO}_{\mathrm{x}}$ trap catalysts $\mathrm{LaCoO}_{3} / \mathrm{K}_{2} \mathrm{CO}_{3} / \mathrm{CeO}_{2}$ using perovskite as active component," Chemical Engineering Journal, vol. 260, pp. 357-367, 2015.

[21] G. S. Qi and W. Li, "NO oxidation to $\mathrm{NO}_{2}$ over manganesecerium mixed oxides," Catalysis Today, vol. 258, part 1, pp. 205213, 2015. 

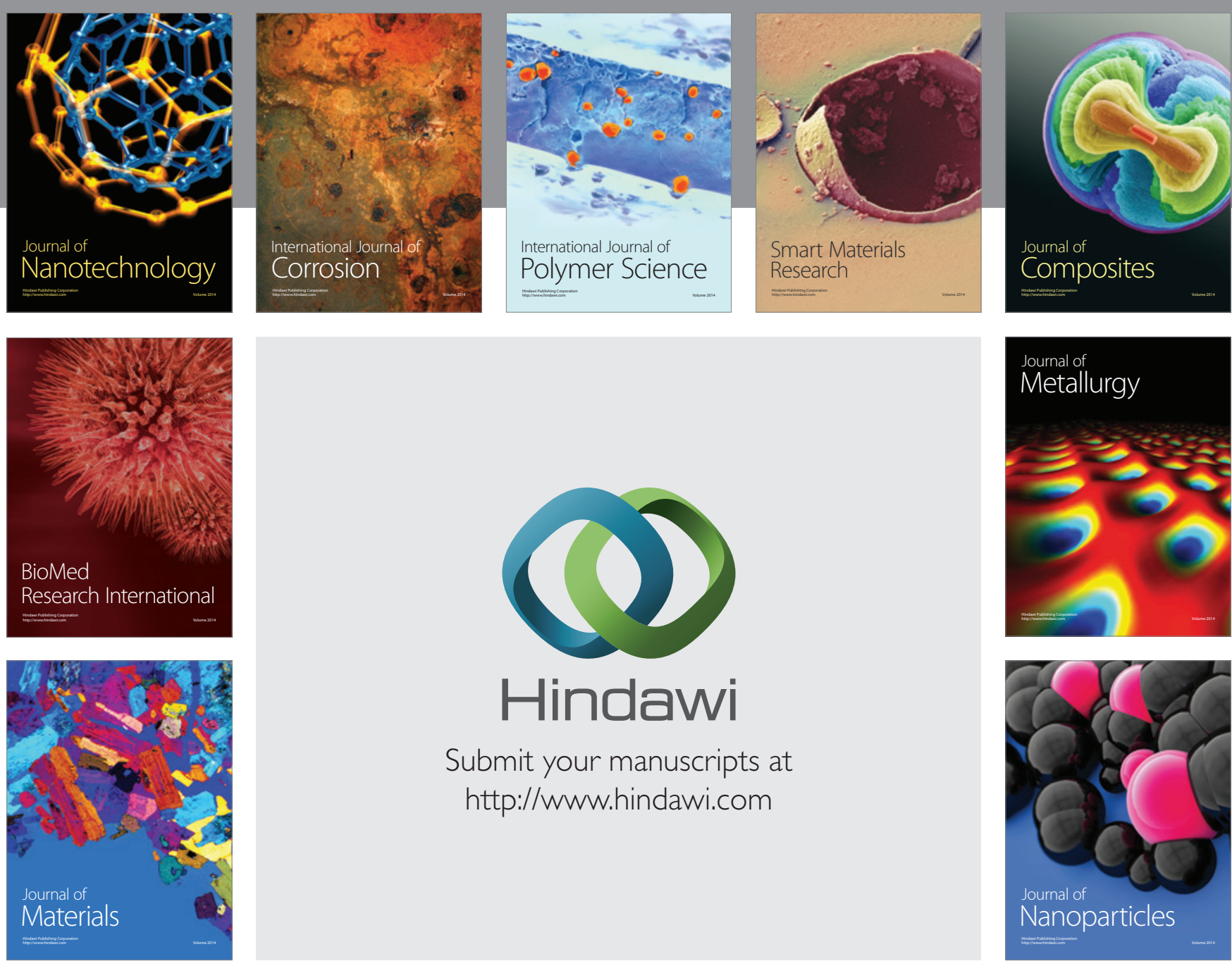

\section{Hindawi}

Submit your manuscripts at

http://www.hindawi.com

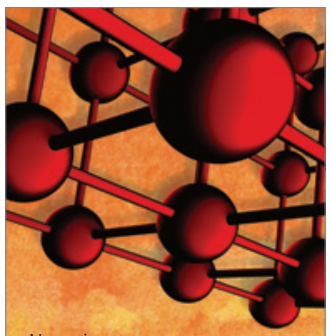

Materials Science and Engineering
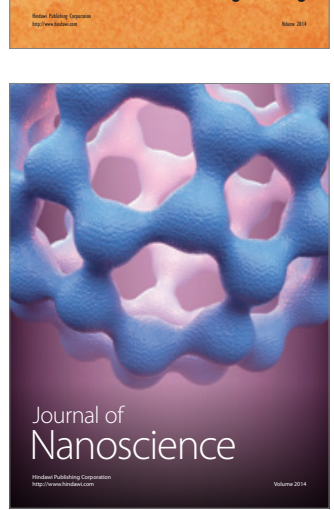
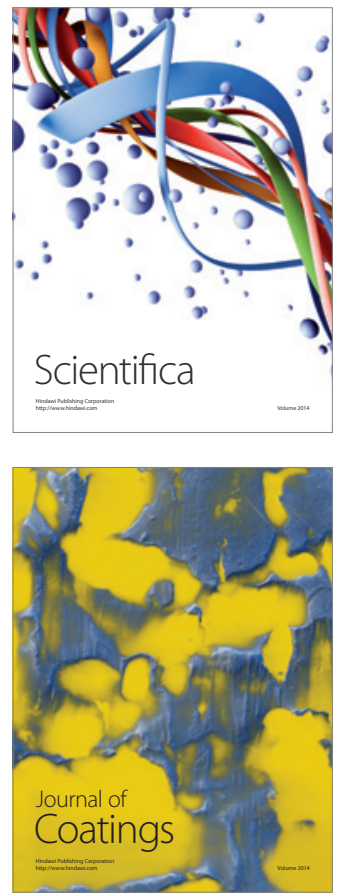
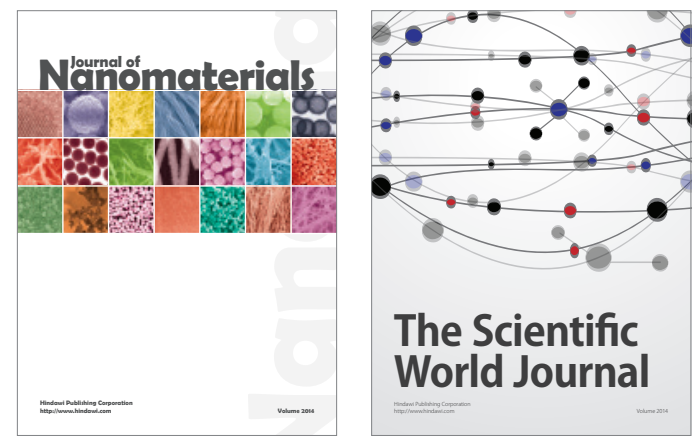

The Scientific World Journal
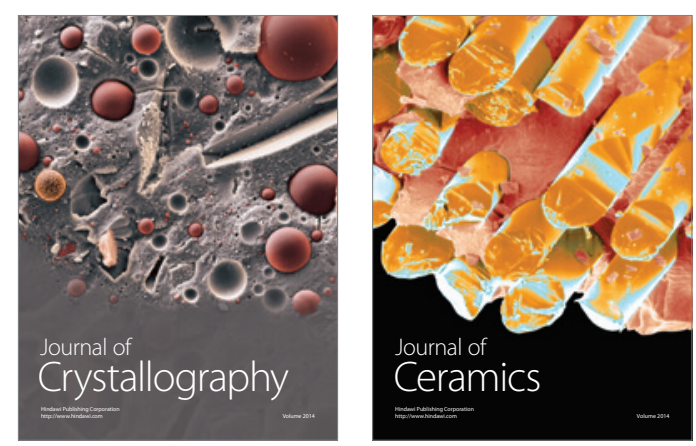
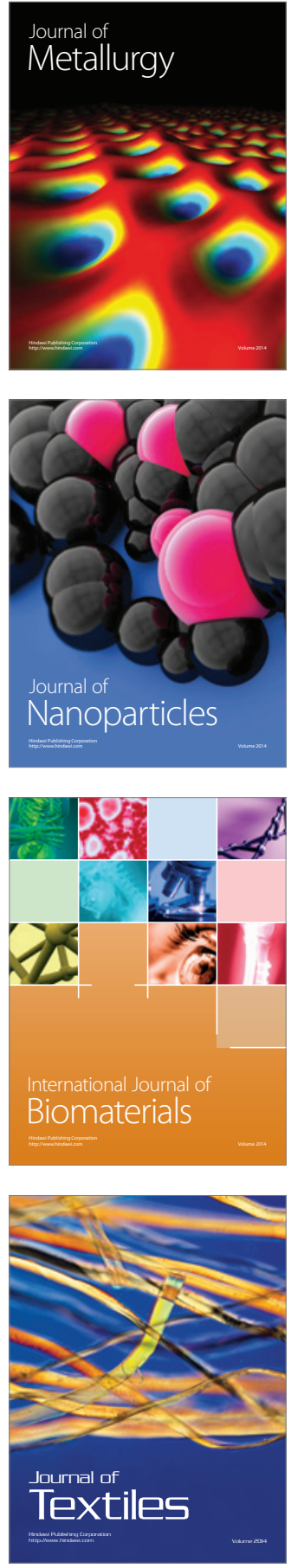